\title{
New Monasticism and the Transformation of American Evangelicalism
}

Rhys Williams

Loyola University Chicago, rwilliams7@luc.edu

Follow this and additional works at: https://ecommons.luc.edu/soc_facpubs

Part of the Sociology Commons

\section{Recommended Citation}

Williams, Rhys. New Monasticism and the Transformation of American Evangelicalism. Reading Religion, , $:$, 2020. Retrieved from Loyola eCommons, Sociology: Faculty Publications and Other Works,

This Book Review is brought to you for free and open access by the Faculty Publications and Other Works by Department at Loyola eCommons. It has been accepted for inclusion in Sociology: Faculty Publications and Other Works by an authorized administrator of Loyola eCommons. For more information, please contact ecommons@luc.edu.

\section{(c) ()@ (ङ)}

This work is licensed under a Creative Commons Attribution-Noncommercial-No Derivative Works 3.0 License. (c) American Academy of Religion, 2020. 


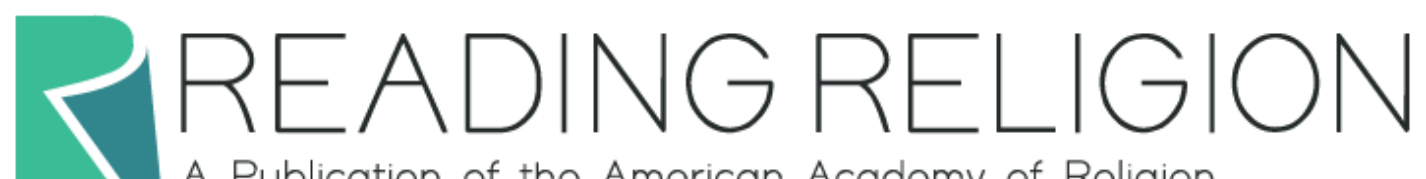

A Publication of the American Academy of Religion

\section{Featured \\ Reviewed \\ Reviews Coming Soon \\ Available for Review}

Review Essays

Author Interviews

About

HOME

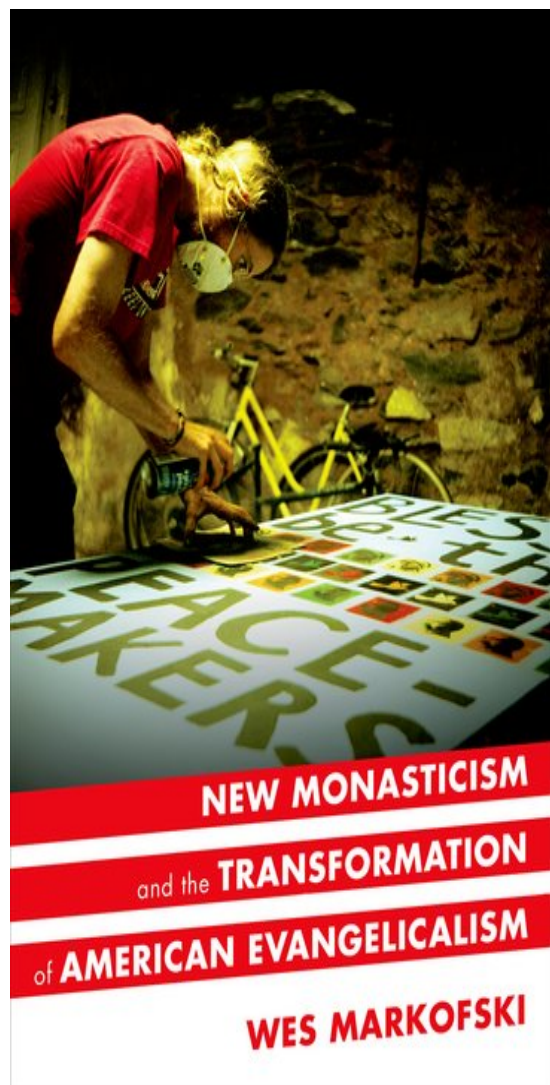

Link to Publisher's Website

New Monasticism and the Transformation of American Evangelicalism 
New York, NY: Oxford University Press, June 2015. 384 pages. \$35.00. Paperback. ISBN 9780190258016.

For other formats: Link to Publisher's Website.

\section{Review}

In New Monasticism and the Transformation of American Evangelicalism, Wes Markofski joins a number of recent scholars who complicate our understanding of white Protestant evangelicalism in the US by arguing that it isn't all politically conservative and ideologically individualist and doesn't form a bulwark population against racial and gender equality, economic redistribution, and social diversity. Given that Donald Trump received 80 percent of the white evangelical vote in 2016, and they haven't quit supporting him, Markofski has his work cut out for him.

Markofski uses an ethnographic case study, combined with prodigious historical and theoretical work, to illuminate one strand of "progressive" evangelicalism, how it works, where it came from, and how it might transform the tradition. The "new monasticism" is a collection of religious communities-often living communally-who purposefully reside in disadvantaged urban neighborhoods, pursue an on-the-ground evangelical politics that is social justice oriented, and engage in intense spiritual community. Markofski cites numbers that show the movement is growing in people who are sympathetic to and involved with it, and in book sales by its leading thinkers. Neo-monasticism uses a "holistic communitarianism" (7) that rejects the theological individualism, and the racial and economic conservatism, of much contemporary evangelicalism.

Of course, all the people who claim to be sympathetic with these core ideas might not call themselves "neo-monastics." But there were organized collective actions even before they were codified into a "movement" and given a label. Like many movements, who counts as in or out is a bit fuzzy. There are networks and loose organizational structures, but nothing approaching institutionalized denominations. Clearly, neomonasticism represents a recent movement within white Protestant evangelicalism, but I wonder about the numbers. Markofski clearly has a handle on a fascinating subculture, but whether this represents a potential threat to the evangelical establishment may be a little wishful thinking. I agree that white evangelicalism is not a monolith. I am less convinced that this is its future.

Be that as it may, this is a deeply informed book, historically and theoretically. The New Monasticism was produced by two movements that were positive inspiration and two that were negative models. The former were the 1970s counter-cultural Jesus People who practiced a liberal communalism and an emotive style of expression, and the "evangelical left" of Sojourners and Evangelicals for Social Action, who found scriptural legitimacy for social justice and confronting poverty and inequality. On the negative side were the Christian Right of the 1980s, who wed "theological individualism, social and economic conservatism, and religious nationalism" (47), and the "megachurch evangelicalism" blooming in white suburbs and exurbs that offers, "folksy communication, evangelistic zeal, and business savvy" (52) with a self-involved and self-satisfied inward focus.

Part 1 of the book covers the history of American evangelicalism and sociological theory about religion. The history explains evangelical religiopolitical divisions in part to understand how the new monastics view themselves within the flow of tradition, and in part to assess how various sociological theories explain evangelicalism. The chapters are informative and well documented, but they are occasionally abstract and formally academic in a way that distracts. For example, Markofski sees race and racial inequality as significant in white evangelicalism's politics, such as when Southern whites justified slavery while Northern whites opposed it. But then the author turns to an examination of existing sociological theories, such as "moral cosmology" theory, and whether they adequately account for this empirical reality. Evangelicals, he argues, have a certain "exception" to moral cosmology theory, and he uses social theorist Pierre Bourdieu to understand how cultural "fields" separate and animate subcultural divisions. Interesting, but "race" disappears.

Markofski lays out Bourdieuian field theory and uses it to chart the ideological and theological positions of the new monastics vis-à-vis other evangelicals. I agree that Bourdieu is more useful than moral cosmology theory, but the excursion into the latter pulls the reader away from Markofski's main contributions by reading too much like an article in a theory journal. I too often lost the thread of the specific communities that are the focus and was not convinced enough by the Bourdieuian field explanation, as it underplays race (at least in my view). Markofski shows that American evangelicalism is not a monolith more effectively with the 'facts on the ground' in neo-monastic communities than with formal typologizing.

Part 2 turns to the "Urban Monastery" as a site. It is a building in a funky neighborhood in a Midwestern city that has both poverty and bohemian gentrification. Those in the Urban Monastery are unusually young compared to the overall evangelical population and disproportionately highly educated. Not all participants actually live communally in the building, but many can walk to events and services there. Two chapters analyze beliefs and religious meanings, and then politics. Both flesh out "holistic communitarianism" with examples from interviews and observations. Neo-monastics are generally social conservative (particularly anti-abortion), yet left-liberal on economics. This is a somewhat lonely political position currently for white evangelicals, but it is actually common among Black evangelicals, a point I wish Markofski had made. The final substantive chapter shows how holistic communitarianism serves as a "relatively coherent and comprehensive strategy for individual and collective action ... a strategy that challenges dominant evangelical approaches to religious organization and social engagement" (225).

Markofski concludes that his book is about the "transformation of American evangelicalism" in two senses. First is the transformation in religious meanings and political positions that is the new monasticism. Second is the Bourdieuian theoretical argument about how evangelicalism as a tradition has been both reproduced and transformed, with new monasticism as an illustrative case. In pursuit of the latter goal the final chapter plunges back into arrows and figures and abstracted processes. It is not easy reading, but it is carefully thought out.

The book is ultimately an analysis of the ideas behind a movement: where they came from, and how they orient and justify action in the world. It has historical depth and ethnographic involvement that give real-life illumination to abstract ideas. For my taste, the ethnographic parts are less immersive than they could be, and are often broken up with abstracted theory. Race is less central to the analysis than I think it should be. I am not as hopeful as the author is. But I learned a great deal and will use the book regularly. 
About the Reviewer(s):

Rhys H. Williams is Professor and Chair of the Sociology Department at Loyola University Chicago.

Date of Review:

August 6, 2020

About the Author(s)/Editor(s)/Translator(s):

Wes Markofski is a doctoral candidate in the department of sociology at the University of Wisconsin-Madison and a graduate research fellow in the Institute for Research on Poverty.

\section{Comments}

Reading Religion welcomes comments from AAR members, and you may leave a comment below by logging in with your AAR Member ID and password. Please read our policy on commenting.

Login 